\title{
Empirical Analysis on Financial Performance through Cash Flow Statements
}

\author{
D. Guna Sankar ${ }^{1} \&$ B. Ravi Kumar ${ }^{2}$ \\ ${ }^{1}$ Department of Accounting and Finance, Ambo University, Ethiopia \\ ${ }^{2}$ Department of MBA, Amrita Sai Institute of Science and Technology, India \\ Correspondence: B. Ravi Kumar, Department of MBA, Amrita Sai Institute of Science and Technology, India \\ To cite this article: Sankar, D. G., \& Kumar, B. R. (2018). Empirical Analysis on Financial Performance through \\ Cash Flow Statements. International Journal of Accounting \& Finance Review, 3(1), 1-12. Retrieved from \\ http://www.cribfb.com/journal/index.php/ijafr/article/view/27
}

Received: September 10, $2018 \quad$ Accepted: September 15, $2018 \quad$ Online Published: September 24, 2018

\begin{abstract}
The present case study is an attempt to anlyze the financial performance of the company by using cash flow statements. The study findings can be helpful for the management of Zuari Cement Ltd., Dondapadu to improve their financial performance and formulate policies that will improve their performance.
\end{abstract}

Keywords: Analysis, Cash Flow Statements, Performance, Zuari Cement Ltd.

\section{Introduction}

A Cash Flow Statement is a statement of changes in the financial position of a firm on cash basis. The working capital concept of fund comprises not only cash/bank but also other current assets and current liabilities. Thus, a change in working capital (Funds) does not necessarily means a change in cash/bank. Such a change may be because of change in non-cash current assets and/or in current liabilities. This leads to the inability of the concern in paying tax and dividends in time.

\section{Utility and Significance of Cash Flow Statement}

A Cash Flow Statement is of primary importance to financial management. At the same time it serves as a 
valuable tool of financial analysis. The main advantages of cash flow statement may be summarized are as follows.

- Cash Flow Statement reveals the causes of changes in cash balances between two balance sheet dates.

- This statement helps the management to evaluate its ability to meet its obligations i.e., payment to creditors, the payment of bank loan, payment of interest, taxed, dividend etc.,

- It throws light on caused for poor liquidity in spite of good profits and excessive liquidity in spite of heavy losses.

- Cash Flow Statement helps the management in planning repayment of loans, replacement of assets etc.

- This statement is helpful in short-term financial decisions relating to liquidity.

\section{Objectives of the Research}

- To study the effectiveness of cash flows of different activities in Zuari Cement Limited and to suggest measures to control cash flows.

- To study the operating activities in Zuari Cement Limited through profit \& Loss Account.

- To study the financing activities through schedules of Balance sheet.

- To study the investment decision that was made by company and to identify the cash/profit incurred through its decision.

- To study about the cash flows those have an impact on the liquidity position.

- To identify the firm's ability to meet its obligation cash flows.

- To analyzes all data collected in the light of determining financial position of firm in handing cash.

- To make necessary recommendation to company an improving cash management.

\section{Data Collection Methods}

\subsection{Primary Data}

Collection of primary data is collected through from the top management in the company. The financial auditor helps me a lot in collecting the information about the cash flow statements.

\subsection{Secondary Data}

The data relating to the financial statement of ZCL have been collected from the published annual reports for the years 2013-2014 to 2017-2018. 


\section{Data Analysis \& Interpretation}

Cash flows statement for the year ended $31^{\text {st }}$ December 2012(rupees in lakhs)

\section{Particulars}

For the year For the year ended

ended $31^{\text {st }}$ December December 2013

2014

(Amalgamated)

\section{Cash flows from operating activities}

Profit before tax

Adjustments:

Depreciation

Amortization of goodwill

Interest and other finance cost

Loss on sale of fixed assets/ assets discarded

Amortization of miscellaneous expenses

Interest income

Dividend income

Profit on sale of current investment

Operating cash flows before working capital changes

(Increase)/decrease in sundry debtors

(Increase)/decrease in loans and advances

Decrease in inventories

Increase in current liabilities and provisions

Cash generated from operations

Taxes(paid)

Net cash provided by operating activities
$28,360.18$

$13,444.82$

$5,204.23$

$2,200.41$

$1,799.20$

950.93

871.49

265.76

450.41

-

67.10

$(1,118.67)$

(60.18)

(0.39)

(1.65)

(194.82)

35,266.42

(76.00)

707.52

$16,896.40$

(1,579.34)

(922.32)

750.52

(291.88)

984.50

$36,130.05$

255.06

$(5,827.03)$

2,765.83

$18,673.09$

$(1,074.02)$

(a)

$30,303.02$

$17,599.07$

\section{Cash flows from investing activities}

Purchase of fixed assets

Proceeds from sale fixed assets

Purchase of shares in SVCL

(17,314.80)

453.53

(16.95)

$(4,950.96)$

$4,003.02$

0.39
$(3,917.45)$

3.71

(951.82)

$(17,756.65)$

$14,024.45$

1.65

Interest received 


\begin{tabular}{|c|c|c|c|c|c|c|c|}
\hline \multirow{3}{*}{$\begin{array}{l}\text { Net } \\
\text { (b) }\end{array}$} & \multirow{3}{*}{ cash } & \multirow{3}{*}{ used } & \multirow{3}{*}{ in } & \multirow{3}{*}{ investing } & \multirow{3}{*}{ activities } & - & $1,598.00$ \\
\hline & & & & & & 826.64 & 61.93 \\
\hline & & & & & & $(16,999.13)$ & $(6,936.18)$ \\
\hline
\end{tabular}

\section{Cash flows from financing activities}

Proceeds from borrowings

Repayment of borrowings

Interest and other finance cost paid

$2,551.31$

$(5,071.07)$

(952.86)

$(9,494.48)$

(975.28)

Net cash used in financing

(c)

Net increase in cash and cash equivalents

(a) $+(\mathbf{b})+(\mathbf{c})$
$9,831.27$

193.13

\section{Interpretation}

- The operating activities shows positive result i.e., 17,599 to 30,303 which shows the miscellaneous expenses almost zero, the dividend income is decreasing and increasing in sundry debtors.

- The net cash in investing activities shows positive result, because of decrease in purchase of fixed assets and also increased in interest received.

- The net cash in financing activities shows positive result, because of decrease in repayment of borrowings.

- The net increase in cash and cash equivalents at the end of the year 2009 shows the positive result.

Cash Flows Statement for the Year Ended $31^{\text {st }}$ December 2013(Rupees in lakhs)

For the year ended For the year ended

$31^{\text {st }}$ December $31^{\text {st }}$ December 2014

2015

\section{Cash flows from operating activities}

Profit before tax

$32,195.97$

$28,360.18$

Adjustments:

Depreciation

Amortization of goodwill

$5,377.68$

$5,204.23$

Interest and other finance cost

$1,799.20$

$1,799.20$

Loss on sale of fixed assets/ assets discarded

534.19

950.93

535.38

265.76 


\footnotetext{
Provision for obsolescence of stores and spares

Loans and advances written off

Stores and spares written off

Provision for bad debts no longer required written

Liabilities no longer required written back

Interest income

Dividend income

Profit on sale of current investment

Operating cash flows before working capital changes

Increase in sundry debtors

(Increase)/decrease in loans and advances

(Increase)/Decrease in inventories

(Increase)/Decrease in current liabilities and

Cash generated from operations

Taxes(paid)
}

provisions

Net cash provided by operating activities (a)

\section{Cash flows from investing activities}

Purchase of fixed assets and capital work in progress

Proceeds from sale fixed assets

Purchase of shares in SVCL

Purchase of long term investment

Purchase of current investment

Proceeds from sale of current investment

Dividend received

Interest received

Net cash used in investing activities (b)

\section{Cash flows from financing activities}

Proceeds from borrowings

Repayment of borrowings

Interest and other finance cost

Repayment of nonconvertible borrowings

Net cash used in financing activities

(c)

Net increase / Decrease in cash and cash equivalents (a) $+(\mathbf{b})+(\mathbf{c})$

$(230.93)$
8.11
347.57

back

(745.19)

$(1,118.67)$

(8.39)

(0.39)

(475.92)

$39,077.03$

(194.82)

(109.09)

$35,266.42$

$(2,942.11)$

707.52

$(2,216.97)$

$(1,579.34)$

750.52

$\begin{array}{lll}\frac{10,079.44}{43,888.30} & \frac{984.50}{36,130.05} \\ \frac{(11,364.05)}{32,524.25} & \frac{(5,827.03)}{30,303.02}\end{array}$

$(54,181.05)$

$(17,314.80)$

13.91

453.53

-

16.95

$(37,933.67)$

$43,360.55$

$(4,950.96)$

8.39

4,003.02

$1,009.81$

0.39

826.64

$(47,722.06)$

$(16,999.13)$ 


\section{Interpretation}

- The net cash flow from operating activities shows positive result. i.e., 30,303 to 32,524 cash flows in operating activities are the principal revenue producing activities.

- The net cash flow from operating activities in the year 2011-2012 is shows the positive performance. This means the profit increased and other finance cost was decreased.

- The net cash flows from investing activities showed positive result. Because of increased in the interest received and also long term investments comes to zero.

- The net cash flows from financing activities shows positive performance by repayment of borrowings are drastically decreased.

- Hence, the net cash and cash equivalents are little bit decreased and overall cash flows showing negative result when compared with previous year.

Cash Flows Statement for the Year Ended $31^{\text {st }}$ December, 2014(Rupees in lakhs)

\section{Particulars}

For the year ended For the year ended

$31^{\text {st }}$ December, $31^{\text {st }}$

2016

\section{Cash flows from operating activities}

Profit before tax

$27,719.24$

$32,195.97$

Adjustments:

Depreciation

$\begin{array}{ll}5,488.32 & 5,377.68 \\ 1,799.20 & 1,799.20 \\ 424.13 & 534.19 \\ 18.59 & 535.38 \\ 50.38 & - \\ - & (230.93) \\ 12.95 & 8.11 \\ 86.89 & 347.57\end{array}$

Amortization of goodwill

Interest and other finance cost

Loss on sale of fixed assets/ assets discarded

Provision for doubtful advances

Provision for obsolescence of stores and spares

Loans and advances written off

Stores and spares written off

86.89

back

Liabilities no longer required written back

Interest income

Dividend income

Profit on sale of current investment

Operating cash flows before working capital changes

Increase in sundry debtors

$-$

$35,080.11$

$39,077.03$

(Increase)/decrease in loans and advances

$(1,244.40)$

(Increase)/Decrease in inventories

$3,610.70$

(Increase)/Decrease in current liabilities and

provisions

$1,606.03$

Cash generated from operations

Taxes(paid)

$(2,283.25)$

$10,079.44$ 
Net cash provided by operating activities

\section{Cash flows from investing activities}

Purchase of fixed assets and capital work in progress

Proceeds from sale fixed assets

Purchase of current investment

Dividend received

Interest received

Net cash used in investing

(b)
$36,769.19$

(a)
$43,886.33$

$(11,362.08)$

$26,846.96$
$(29,552.81)$

20.02

$(1,03,807.41)$

$92,143.32$

activities

182.94

$1,128.28$

$(39,885.66)$
$(54,181.05)$

13.91

$(37,933.67)$

$43,360.55$

8.39

$1,009.81$

\section{Cash flows from financing activities}

Proceeds from borrowings

Repayment of borrowings

Interest and other finance cost

Repayment of nonconvertible borrowings

Net cash used in financing activities

(c)

$36,645.37 \quad 10,915.03$

$(2,151.36)$

$(1,575.00)$

$(5,146.89)$

(534.19)

$\frac{-}{29,347.12} \frac{(846.72)}{7,959.12}$

\section{Net increase / Decrease in cash and cash equivalents}

(a) $+(\mathbf{b})+(\mathbf{c})$

\section{Interpretation}

- In the year 2012-2013 the operating activities show the decreasing trend i.e., from 32,524 to 24,846. The operating activities are the key indicators to which the operation of an enterprise has generated cash flows to maintain operating capability of the enterprise.

- The net cash flow fromoperating an activity in the 2012-2013 is not showed the positive performance. Because of decrease in profit, increase in depreciation, increase in loans \& advances and also increase in the sundry debtors.

- The net cash flows from investing activities are the acquisition \& disposal of long term assets. 
- The investing activities are shows positive performance. Because of sales fo fixed assets increased, purchase of fixed assets decreased and also increased in the dividend \& interest income.

- The net cash flows from financing activities show the positive trend. This means of increase in borrowings. Cash Flow Statement for the year ended $31^{\text {st }}$ December, 2015(Rupees in lakhs)

For the year ended For the year ended

$31^{\text {st }}$ December, 31 ${ }^{\text {st }}$ December, 2016

2017

\section{Cash flows from operating activities}

Profit before tax

Adjustments:

Depreciation

Amortization of goodwill

Interest and other finance cost

Loss on sale of fixed assets/ assets discarded

Provision for doubtful advances

Provision for obsolescence of stores and spares

Loans and advances written off

Stores and spares written off

Provision for site restoration

Provision for doubtful advances no longer required written back

Provision for doubtful debts

Liabilities no longer required written back

Interest income

Dividend income

Profit on sale of current investment

Operating cash flows before working capital changes

Increase in sundry debtors

(Increase)/decrease in loans and advances

(Increase)/Decrease in inventories

(Increase)/Decrease in current liabilities and

Cash generated from operations

Taxes(paid)

\section{Net cash provided by operating activities}

\section{Cash flows from investing activities}

Purchase of fixed assets and capital work in progress

Proceeds from sale fixed assets

Purchase of current investment
$5,062.88$

$27,719.24$

$8,160.36$

$5,488.32$

$1,799.20$

$1,799.20$

$3,439.37$

424.13

65.84

18.59

$-$

50.38

21.14

22.14

12.95

59.40

86.89

91.40

(9.77)

-

(937.40)

(277.34)

(157.49)

(141.42)

(116.50)

(29.98)

$17,759.75$

$35,080.11$

(191.19)

$(1,244.40)$

$(2,244.75)$

3,610.70

$(4,763.72)$

$1,606.03$

provisions

$\frac{10,293.34}{20,873.43} \frac{(2,283.25)}{36,769.19}$

(a)

\begin{tabular}{l}
$(3,882.66)$ \\
$16,990.77$ \\
\hline
\end{tabular}

$(9,922.23)$

$26,846.96$
$(40,628.70)$

$(29,552.81)$

28.48 


\begin{tabular}{llll} 
Proceeds from sale of current investment & $(52,169.03)$ & $(1,03,807.41)$ \\
Investment in subsidiary & $62,117.59$ & $92,143.32$ \\
Dividend received & - & - \\
Interest received & 322.18 & 182.94 \\
Net cash used $\quad$ in investing & activities & $\frac{929.94}{(29,399.54)}$ & \\
(b) & & \multicolumn{2}{l}{$\frac{1,128.28}{(39,885.66)}$} \\
\end{tabular}

\section{Cash flows from financing activities}

Proceeds from borrowings

$44,344.59 \quad 36,645.37$

Repayment of borrowings

$(42,750.00)$

$(2,151.36)$

Interest and other finance cost

$\begin{array}{lllll}\text { Net cash used in financing activities } \frac{(5,717.25)}{(4,122.66)} & \frac{(5,146.89)}{29,347.12} \\ \text { (c) } & & \end{array}$

Net increase / Decrease in cash and cash equivalents (a)+(b)+(c)

\section{Interpretation}

- The net cash flow from operating activities in the year 2013-2014 is falls drastically from 26,846 to 16,990 .

- The net cash flow from operating activities is shows negative performance. Because of Increased in depreciation, increased in other finance cost and increased in the sundry debtors.

- The net cash flow from investing activities is shows the positive performance. By decreased in the current investment and increased in the dividend received.

- The net cash flows from financing activities are shows negative result.

Cash Flow Statement for the Year Ended $31^{\text {st }}$ December, 2016(Rupees in lakhs)

\begin{tabular}{|c|c|c|}
\hline & For the year ended & For the year ended \\
\hline & December, & December, \\
\hline & 2018 & 2017 \\
\hline \multicolumn{3}{|l|}{ Cash flows from operating activities } \\
\hline Profit before tax & $15,390.09$ & $5,062.88$ \\
\hline \multicolumn{3}{|l|}{ Adjustments: } \\
\hline Depreciation & $11,339.49$ & $8,160.36$ \\
\hline Amortization of goodwill & $1,799.20$ & $1,799.20$ \\
\hline Interest and other finance cost & $5,607.36$ & $3,439.37$ \\
\hline Loss on sale of fixed assets/ assets discarded & 6.60 & 65.84 \\
\hline Provision for doubtful advances & 16.91 & - \\
\hline
\end{tabular}




\section{Provision for obsolescence of stores and spares}

Loans and advances written off

Stores and spares written off

Provision for site restoration

Provision for doubtful advances no longer required written back

Provision for doubtful debts

Liabilities no longer required written back

Interest income

Dividend income

Profit on sale of current investment

Operating cash flows before working capital changes

Increase in sundry debtors

(Increase)/decrease in loans and advances

(Increase)/Decrease in inventories

(Increase)/Decrease in current liabilities and

provisions

$\begin{array}{ll}171.49 & 21.14 \\ - & 22.14 \\ - & 59.40 \\ 104.70 & 91.40\end{array}$

(5848)

$(9.77)$

2.82

(141.86)

(937.40)

$(1,055.15)$

(277.34)

$-$

(429.19)

$32,753.98$

(29.98)

(892.59)

$17,759.75$

$(7,693.75)$

(191.19)

$(3,311.92)$

$(2,244.75)$

$(4,763.72)$

$7,623.32$

$10,293.34$

Cash generated from operations

Taxes(paid)

\section{Net cash provided by operating activities}

\section{Cash flows from investing activities}

(a)

$$
28,479.04
$$

$$
20,873.43
$$

$\frac{(3,391.25)}{25,087.79}$

$\frac{(3,882.66)}{16,990.77}$

Purchase of fixed assets and capital work in progress

Proceeds from sale fixed assets

Purchase of current investment

Proceeds from sale of current investment

Investment in subsidiary

Dividend received

Interest received

\section{Net cash used in investing activities}

\section{Cash flows from financing activities}

$\begin{array}{ll}(24,395.97) & (40,628.70) \\ 37.44 & 28.48 \\ (34,650.00) & (52,169.03) \\ 31,029.46 & 62,117.59 \\ (5,782.49) & - \\ - & 322.18\end{array}$

(b) $\frac{1,025.18}{(32,736.38)}$

929.94

$(29,399.54)$

Proceeds from borrowings

Repayment of borrowings

Interest and other finance cost

Net cash used in financing activities
Net cash used in financing activities
Net increase / Decrease in cash and
equivalents $(\mathbf{a})+(\mathbf{b})+(\mathbf{c})$

$21,763.16$

(c) $(501.93)$

$(5,729.55)$

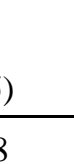

$44,344.59$

$(42,750.00)$

$(5,717.25)$

$(4,122.66)$ 


\section{Interpretation}

- The net cash from operating activities shows the positive performance. i.e., from 16,990 to 25,087

- The net cash flows from operating activities are increased. Due to, Loans and advances written off comes to zero.

- The net cash flows from investing activities are shows positive performance. Why because of purchase of fixed assets is decreased, current investment is also decreased.

- The net cash flows from financing activities showed positive result. Because, decrease in borrowings and repayment of borrowings.

\section{Findings}

- The study reveals investing, operating and financing activities shows the positive result, where the firm maintaining most of liquidity cash to run day to day activities.

- It may conclude from the analysis, the net cash flows from investing activities are highly increased. Due to purchase of fixed assets affects on the net cash and cash equivalents.

- The net cash flows from operating activities, profit is slightly decreased and the fixed assets are sold hugely and sale of current investment is increased these leads to generated cash flows and cash equivalents.

- As it is clear stated the impact on profit before tax and these leads to decrease in net operating activities and also these shows the impact on the net cash and cash equivalents.

- It can be finalized, the profits was slightly increased that leads to the net operating profit also increased. And, investing activities shows also positive indicators. Repayment of borrowings is also decreased and these lead to net cash and cash equivalents.

\section{Suggestions}

- It is suggested to the company authorities to increase the operating, financing and investing activities to improve for the future prospects of business concern.

- By observing the above statement the company tries to reduce some investment on long term investment for meet the present expenses of a firm. If the company continue the same the company unable to meet the day to day expenses.

- While examining into the contents, the profit before tax is slight decreased and try to recollect the sundry debtors.

- As reported by the study, try to maintain the minimum profits and reduce interest, other finance cost.

- It is suggested to company authorities' focus on the proceeds from borrowings and operating activities to generate the optimum profit.

\section{References}

Jahangir, N., Shill, S., and Haque, M. A. J. (2007). Examination of Profitability in the Context of Bangladesh Banking Industry. ABAC Journal, 27(2).

Chowdhury, Tanbir Ahmed., and Kashfia Ahmed (April, 2009), "Performance Evaluation of Selected Private Commercial Banks in Bangladesh". International Journal of Business and Management, 4(4).

Siddique, S. H., and Islam, A. F. M. M. (2001). "Banking Sector in Bangladesh: Its Contribution and Performance". Journal of Business Research, Jahangirnagar University,3(1).

International Finance Corporation (IFC). (2013). Scoping study of foreign exchange business in Bangladesh, Bangladesh. 
Business Development Conference.( 2013). Study on foreign exchange operations in Bangladesh, Bangladesh. Press Release.(2013). National Bank Limited, 2010-2013. Avilable from: Press Release, National Bank Limited. Ahmed, M., B. (2009). Measuring the Performance of Islamic Banks by Adapting Conventional Ratios German University in Cairo Faculty of Management Technology, Working Paper, 16(1), 1-26.

Baxter, R. (2008). The global economic crisis and its impact on South Africa and the country's mining industry South African Reserve bank conference papers [Online] Available at: http://www.reservebank.co.za/internet/publication.nsf/WCEV/498F27F900B18F27422576010035EE9 2/?opendocument [Accessed 14 June 2010]

Berger, A.N. and Humphrey, D.B. (1997). Efficiency of financial institutions: international survey and directions for future research. European Journal of Operational Research, 98(1),175-212.

Dietrich, J. (1996). Financial Services and Financial Institutions: Value Creation in Theory and Practice Prentice Hall.

\section{Copyrights}

Copyright for this article is retained by the author(s), with first publication rights granted to the journal.

This is an open-access article distributed under the terms and conditions of the Creative Commons Attribution license (http://creativecommons.org/licenses/by/4.0/). 